\title{
Anatomical Study of the Fibularis Longus Muscle Motor Points and Electrical Stimulation Therapy Application
}

\author{
Estudio Anatómico de los Puntos Motores del Músculo Fibularis Longus \\ y su Aplicación en la Terapia de Electroestimulación
}

Guillermo Méndez Rebolledo ; Roberto Coronado Gallardo \& Iván Suazo Galdames

MÉNDEZ, R. G.; CORONADO, G. R. \& SUAZO, G. I. Anatomical study of the fibularis longus muscle motor points and electrical stimulation therapy application. Int. J. Morphol., 27(3):699-703, 2009.

SUMMARY: The fibularis longus muscle (FLM) has an important role in the movement of eversion of the foot and in maintaining the plantar arch. The electrostimulation procedures seek to maintain muscle trophism, increase strength and endurance, and are frequently used in physiotherapy, for which the clinician needs to know the location of the motor points of the FLM. Therefore, the purpose of this study was to determine the number and distribution of motor points of the FLM and relate them to observable parameters in the surface anatomy. Ten formalin-preserved limbs were used, and the lateral regions of the leg were dissected in detail. In all the cases, the muscle presented three fascicular patterns, the superior and anteroinferior fascicles presented two motor points each, while the posteroinferior fascicles were between 2 and 3 motor points. Our results suggest that there is a pattern of distribution of the superficial fibular nerve, whose knowledge is useful for clinical application in the FLM electrostimulation proceedings.

KEY WORDS: Fibularis longus muscle; Superficial fibular nerve; Motor Point; Electrostimulation.

\section{INTRODUCTION}

In the musculoskeletal system and neural-structure injuries, the clinical objective is to maintain the muscle trophism, and increase the strength and endurance, for which, since 1960, electrostimulation has been used to induce action potentials in the excitable cells, nerve, or muscle, by an electrical pulse (Rodríguez, 2004; Pombo, 2004). For efficient stimulation, it is necessary to know the motor innervation of the muscles and their variations, especially the localization of motor points (Albert et al., 2000; Olave et al., 2002).

The fibularis longus muscle (FLM) belongs to the lateral compartment of the leg and its function allows the eversion of the foot, providing stability in the frontal plane, and participates in the formation of the plantar arch (Wildenauer \& Muller, 1954; Kapandji, 2001; Nordin \& Frankel, 2004; Miralles \& Miralles, 2005). This muscle or its innervation may be injured by clinical maneuvers, such as compression bandages, fasciotomies, arthroscopic portals, surgical approaches for osteosynthesis, etc. (Jackson \& Waugh, 1974; Aydog đu et al., 1996; Pacha et al., 2003). In these cases, the rehabilitation procedures will include electrostimulation, which requires a detailed knowledge of the motor points of FLM.

Despite the clinical relevance of the FLM motor point locations, there are only a few studies and limited information on the determination of surface benchmarks. According to Latarjet and Ruiz-Liard (1999), the FLM has three fascicles or fiber groups that are innervated by two motor branches from the superficial fibular nerve (SFN), while Bakkum et al. (1996) described the existence of four FLM fascicles that are innervated by a collateral branch from the SFN.

Against this background, the purpose of this study was to describe the location of the motor points of FLM and the handing benchmarks for its location on the surface anatomy of the crural region. 


\section{MATERIAL AND METHOD}

We used 10 lower limbs of adult cadavers (6 left and 4 right) of both genders ( 1 woman and 4 men), aged 45-65 years, fixed and preserved in 10\% formalin solution, provided for academic purposes by the Morphology laboratory, Universdad de Talca and Laboratory of Anatomy of the Universidad de la Frontera. The lower limbs were well-preserved without evidence of lesions in the knee, crural, talocrural, and foot regions.

The lower limbs were placed in an intermediate position between the supine and lateral positions, so that the lateral compartment of the leg was in a better position to dissection (Pelozo, 2000). The skin and the subcutaneous tissue were withdrawn for the purpose of accessing the muscles of the lateral compartment of the leg, exposing the tip of the fibula head and the distal part of the lateral malleolus. The nerve was exposed through common fable resection of the related structures, from the popliteal fossa and its path through the lateral zone of the leg, to the upper end of the FLM, and then was moved medially, accessing the SFN, its muscular branches, and FLM motor points (Fig. 1).

Each motor point was marked with pins projecting its location on the muscle surface, and the displaced muscle was sutured in its anatomic position, showing only the projections of each motor point (Figs. $2 \mathrm{~A}$ and B).
Later, a line was drawn between the head of the fibula to the distal portion of the lateral malleolus (HML), and one perpendicular line to it, which made contact with the motor points marked with pins, was measured using a digital caliper (0.01 mm) (Fig. 3).

The results were processed by the statistical program, SPSS15.0 that calculated the descriptive statistics.

\section{RESULTS}

In all the limbs analyzed in this study, the FLM was innervated by the SFN, which gave 2 or 3 principle branches to the muscle groups that provided a variable number of nerve branches, resulting in 7-9 motor points.

In the group of superior fibers, 3 motor points for each FLM were found, and the average distance to the HML line was $5.66 \mathrm{~mm}$ (SD: $7.3 \mathrm{~mm}$ ). In the anteroinferior fibers, 2 motor points foreach FLM were observed, and the average distance to the HML line was $8.55 \mathrm{~mm}$ (SD: $10.9 \mathrm{~mm}$ ). In the FLM posteroinferior fibers, 7 muscles presented 3 motor points, and 3 of them had 2 motor points. In this group of fibers, the motor points were located anterior and posterior to the HML line, and the average distance to the motor

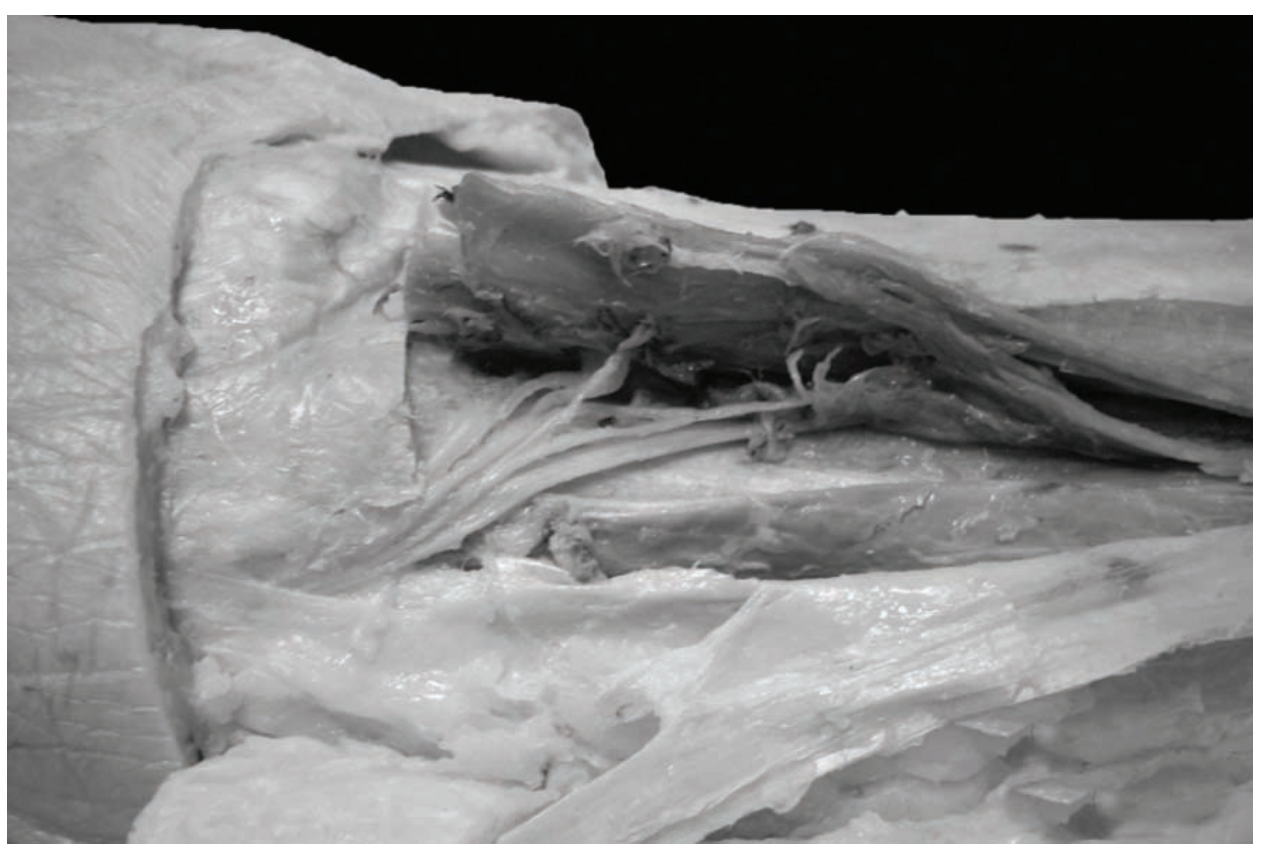

Fig. 1. Proximal desinsertion of fibularis longus muscle moved medially. 

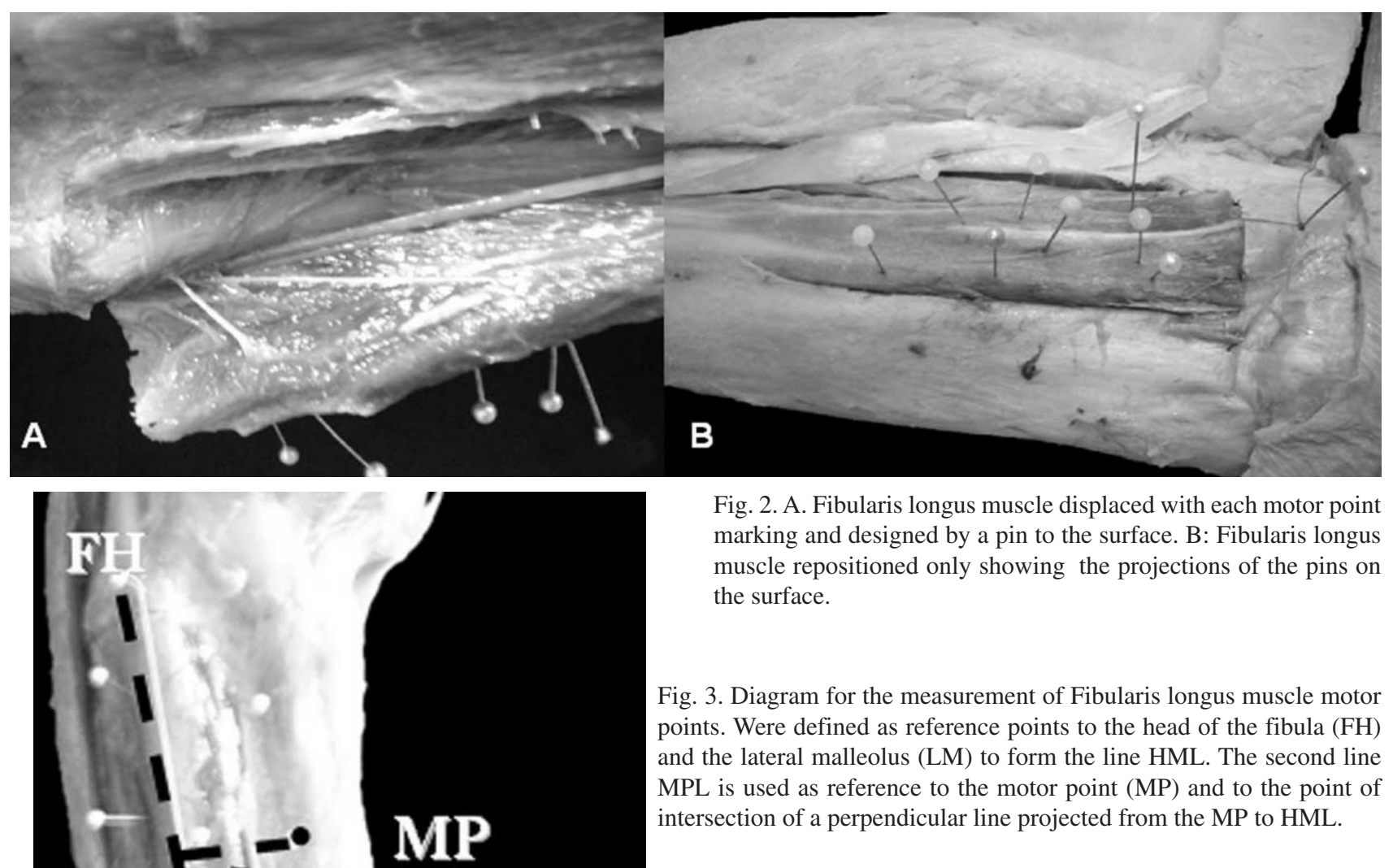

Fig. 2. A. Fibularis longus muscle displaced with each motor point marking and designed by a pin to the surface. B: Fibularis longus muscle repositioned only showing the projections of the pins on the surface.

Fig. 3. Diagram for the measurement of Fibularis longus muscle motor points. Were defined as reference points to the head of the fibula $(\mathrm{FH})$ and the lateral malleolus (LM) to form the line HML. The second line MPL is used as reference to the motor point (MP) and to the point of intersection of a perpendicular line projected from the MP to HML.

point was $-1.77 \mathrm{~mm}$ (SD: $5.7 \mathrm{~mm}$ ) and the median was -3.170 $\mathrm{mm}$, with a maximum value of $8.54 \mathrm{~mm}$ and a minimum value of $-9.71 \mathrm{~mm}$.

\section{DISCUSSION}

Determining the number and position of the motor points of the FLM is important for the electrostimulation procedures (Rodríguez). In our study, we found three fascicular patterns of FLM in all the limbs studied, which is in agreement with the classical literature (Latarjet \& RuizLiard), but differs from those reported in other studies (Bakkum et al.). On the other hand, each of these fascicles presented a variable number of motor points, suggesting a more complex distribution of motor branches of the SFN than that described in the classical literature (Latarjet \& RuizLiard; Testut \& Latarjet, 1999; Paturet, 1951; Moore \& Dalley, 2007; Rouvière \& Delmas, 2005), which is important both for electrostimulation and surgical procedures that are performed in the area (Barrett et al., 2006; Matejcik et al., 2001). However, the limited number of studies makes it difficult to contrast our results and discuss the validity of the maps for electrostimulation as the basis for most of the treatment protocols (Reid, 1920; Adams et al., 1993). 
MÉNDEZ, R. G.; CORONADO, G. R. \& SUAZO, G. I. Estudio anatómico de los puntos motores del músculo fibularis longus y su aplicación en la terapia de electroestimulación. Int. J. Morphol., 27(3):699-703, 2009.

RESUMEN: El músculo fibular largo (MFL) tiene una importante función en el movimiento de eversión del pié y en la mantención del arco plantar. Los procedimientos de electroestimulación buscan mantener el trofismo muscular, aumentar la potencia y resistencia y es frecuente su utilización en fisioterapia, para ello el clínico necesita conocer la localización de los puntos motores del MFL, por ello, el propósito de este estudio fue determinar el número y distribución de los puntos motores del MFL y relacionarlos con parámetros observables en la anatomía de superficie. Se utilizaron 10 miembros inferiores conservados y se disecó detalladamente la región lateral de la pierna. El músculo presentó en todos los casos una estructura trifascicular, los fascículos superiores y anteroinferiores presentaron dos puntos motores cada uno, mientras en el fascículo posteroinferior encontramos entre 2 y 3 puntos motores. Nuestros resultados sugieren que existe un patrón de distribución del nervio fibular superficial cuyo conocimiento es de utilidad clínica para los procedimientos de electroestimulación del MFL.

PALABRAS CLAVE: Músculo fibularis longus; Nervio fibular superficial; Punto motor; Electroestimulación.

\section{REFERENCES}

Adams, G. R.; Harris, R. T.; Woodard, D. \& Dudley, G. A. Mapping of electrical muscle stimulation using MRI. J. Appl. Physiol., 74(2):532-7, 1993.

Albert, T.; Yelnik, A.; Colle, F.; Bonan, I. \& Lassau, J. P. Anatomic motor point localization for partial quadriceps block in spasticity. Arch. Phys. Med. Rehabil., 81(3):285-7, 2000.

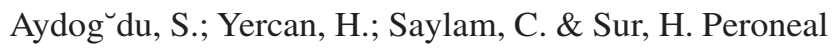
nerve dysfunction after high tibial osteotomy. An anatomical cadaver study. Acta Orthopeadic. Belg., 62(3):156-60, 1996.

Bakkum, B. W.; Russell, K.; Adamcryck, T. \& Keyes, M. Gross anatomic evidence of partitioning in the human fibularis longus and brevis muscles. Clin. Anat., 9:3815, 1996.

Barrett, S. L.; Dellon, A. L.; Rosson, G. D. \& Walters, L. Superficial peroneal nerve (superficial fibularis nerve): the clinical implications of anatomic variability. J. Foot Ankle Surg., 45:174-6, 2006.

Jackson, J. P. \& Waugh, W. The technique and complications of upper tibial osteotomy. A review of 226 operations. J. Bone Joint Surg. Br., 56(2):236$45,1974$.

Kapandji, A. Fisiología Articular. Esquemas Comentados de Mecánica Humana. Madrid, Médica Panamericana, 2001. p.222.

Latarjet, M. \& Ruiz-Liard, A. Anatomía Humana. Madrid, Panamericana, 1999. pp. 864-6, 940-7.
Matejcik, V.; Steno, J.; Benetin, J. \& Kuchar, M. Surgical treatment of injuries of nervus fibularis. Bratisl. Lek. Listy, 102:361-4, 2001.

Miralles, R. \& Miralles, I. Biomecánica Clínica de los Tejidos y de las Articulaciones del Aparato Locomotor. $2^{\circ}$ Edi. Barcelona, Masson, 2005. p.271, 283.

Moore, K. \& Dalley, A. Anatomía con Orientación Clínica. Buenos Aires, Editorial Médica Panamericana, 2007. pp.644, 703-7.

Nordin, M. \& Frankel, V. Biomecánica Básica del Sistema Musculoesquelético. $3^{\circ}$ Ed. Madrid, McGraw-Hill/ Interamericana, 2004. pp.229, 243-4.

Olave, E.; Gabrielli, C.; Braga, M. T. T. \& Del Sol, M. Aspectos biométricos de los ramos motores del nervio musculocutáneo para el músculo braquial. Rev. Chil. Anat., 20(2):231-6, 2002.

Pacha, D.; Carrera, A.; Llusa, M.; Permanyer, E.; Molona, O. \& Morro, R. Clinical anatomy of the superficial peroneal nerve in the distal leg. Eur. J. Anat., 7(1):15$20,2003$.

Paturet, G. Traité d'anatomie humaine: membres supérieur et inférieur. Paris, Masson, 1951. pp.1073-85.

Pelozo, O. Distribução dos ramos do nervo fibular comun para os musculos dos compartimentos anterior e lateral da perna. Tese (Mestre) Universidade Federal de São Paulo. Escola Paulista de Medicina, 2000.

Pombo, F. M. Electroestimulación: Entrenamiento y 
MÉNDEZ, R. G.; CORONADO, G. R. \& SUAZO, G. I. Anatomical study of the fibularis longus muscle motor points and electrical stimulation therapy application. Int. J. Morphol., 27(3):699-703, 2009.

Periodización. Aplicación Práctica al fútbol y 45 deportes. $1^{\circ}$ Ed. Barcelona, Paidotribo, 2004 p.11.

Reid, R. Motor points in relation to the surface of the body. J. Anat., 54(4):271-5, 1920.

Rodríguez, M. Electroterapia en Fisioterapia. $3^{\circ}$ Ed. Buenos Aires, Panamericana, 2004. pp.317-58.

Rouvière, H. \& Delmas, A. Anatomía Humana: Descriptiva, Topográfica y Funcional. Madrid, Elsevier, 2005. pp.512-5.

Testut, L. \& Latarjet, A. Compendio de Anatomía Descriptiva. Barcelona, Salvat, 1999. pp.494-6.

Wildenauer, E. \& Muller, W. The effects of the musculus fibularis longus on the transverse and lateral longitudinal arch of the foot. Arch. Orthop. Unfallchir, 46:406-10, 1954.
Correspondence to:

Prof. Dr. Iván Suazo Galdames

Department of Morphology

Avenida Lircay s/n oficina $\mathrm{N}^{\circ} 104$

Universidad de Talca, CHILE

Phone: 56-71-201576

Email: isuazo@utalca.cl

Received: 22-06-2009

Accepted: 12-08-2009 
